\title{
Association between the thickness of the collagen in the amniotic membrane with the incidence of premature rupture of membranes
}

\author{
Johny Marpaung*
}

Department of Obstetrics and Gynecology, Faculty of Medicine, University of Sumatera Utara, Medan Indonesia

Received: 7 October 2015

Revised: 5 January 2016

Accepted: 8 January 2016

\section{*Correspondence:}

Dr. Johny Marpaung,

E-mail: johnymarpaung@ymail.com

Copyright: $\odot$ the author(s), publisher and licensee Medip Academy. This is an open-access article distributed under the terms of the Creative Commons Attribution Non-Commercial License, which permits unrestricted non-commercial use, distribution, and reproduction in any medium, provided the original work is properly cited.

\begin{abstract}
Background: Neonatal Mortality Rate in Indonesia is 19 deaths/1,000 live births and IMR is 32 deaths/1,000 live births which can be associated with the incidence of premature rupture of membranes (PROM). In America, PROM occurs in $2-3 \%$ of all pregnancies and $40 \%$ associated with preterm birth. Some studies indicate a difference in the thickness of the collagen in the membrane architecture cause structural abnormalities that occur in PROM.

Methods: This study is an observational analytic study with cross sectional study design to see the difference in the thickness of the collagen membrane of the amnion PROM patients with normal pregnant patients conducted in the Department of Obstetrics and Gynecology, Faculty of Medicine USU-General Hospital of Adam Malik, and District Hospital USU on December 2014-March 2015. Sampling was carried out in the delivery room and operating room in General Hospital of Adam Malik. Data analysis was performed by univariate analysis to find the characteristics of the sample and bivariate analysis to compare the thickness of the collagen in amnion membranes at term PROM patients and normal pregnant.

Results: This study showed the thickness of the collagen mother with PROM was $108.11 \pm 14.06$ mm thinner than the average thickness of the collagen normal pregnant women which was $172.06 \pm 38.40 \mathrm{~mm}$. And the thickness of amniotic mother with PROM was $522.72 \pm 85.63 \mathrm{~mm}$ thinner than the thickness of normal pregnant women amnion was $702.72 \pm 180.07 \mathrm{~mm}$.

Conclusions: Statistical test result with t-test. p value $<0.05$ showed a significant difference collagen thickness and amnion thickness at PROM group with normal pregnant group that showed an association with the PROM and collagen thickness.
\end{abstract}

Keywords: Collagen thickness, Amnion thickness, PROM

\section{INTRODUCTION}

Neonatal Mortality Rate in Indonesia is about 19 deaths/1,000 live births and IMR is 32 deaths/1,000 live births which can be associated with the incidence of premature rupture of membranes (PROM). In America, PROM occurs in $3 \%$ of all pregnancies. In other studies, PROM occurs in $2 \%$ of all pregnancies and associated with $40 \%$ of preterm birth and causes morbidity and mortality.
PROM can occur at term or preterm gestational age. Morbidity and mortality are higher in preterm premature rupture of membranes associated either independently or with increased rates of premature birth. One mechanism of premature rupture occur due to interference the initial activation process of weakening membrane at term. ${ }^{3,4}$

Several authors have examined the collagen content of the fetal membranes to show the differences in the architecture of the membrane which is associated with structural abnormality causes resulting in the occurring of 
PROM, by comparing the content of collagen in nine amnion of PROM labor with ten amnion of premature labor without the premature rupture. They concluded that the reduction in particular of collagen type III (which serves as a support in the extracellular matrix membrane) would reduce the tensile strength properties of chorioamniotic membrane. $^{2}$

\section{METHODS}

This study is an observational analytic study with cross sectional study design to see the difference in the thickness of the collagen membrane of the amnion PROM patients with normal pregnant patients conducted in the Department of Obstetrics and Gynecology, Faculty of Medicine USU -General Hospital of Adam Malik, and Hospital Network USU in December 2014 - March 2015.Samples in this study were half of study population that labored in General Hospital of and Hospital Network Medicine Faculty of USU. Samples were taken in delivery and operation room of General Hospital of Adam Malik Medan.

In this study, data analysis and statistical tests performed by univariate analysis to look at the characteristics of the sample and bivariate analysis to compare the thickness of the collagen in amnion membranes at term PROM patients and normal pregnant. Used independence t-test with a $95 \%$ confidence level $(\alpha=0.05)$. This study has also received approval from the health research ethics committee of the Faculty of Medicine, University of North Sumatra.

\section{RESULTS}

This study used a sample case of premature rupture of membranes (PROM) and normal amniotic each as much as 23 people. In this study it was found that the characteristics of mothers in the study group PROM mostly aged $31-35$ years $(39.1 \%)$ and the lowest at age $36-40$ years $(8.7 \%)$, as well as in the study group with normal pregnant women most at age 31-35 - 35 years $(34.8 \%)$ and the lowest at age $36-40$ years $(8.7 \%)$ (Table 1). Statistical test result with the Fisher exact test $p$ value $>0.05$ showed no significant age differences between groups of pregnant women with PROM and normal.

Furthermore, based on parity mothers showed that the study group mothers with PROM with more parity 0 (47.8\%) and the lowest with parity 2-3 (21.7\%). Whereas in the study group with normal pregnant mothers also showed that most of the parity $0(47.8 \%)$ and the lowest with parity 2-3 (17.4\%) (Table 1). Statistical test result with the Fisher exact test $\mathrm{p}$ value $>0.05$ showed no significant differences parity between mother with PROM and normal pregnancy mother.

Table 1: Distribution characteristics of the study subjects according to age, gender, education level and gravida.

\begin{tabular}{|c|c|c|c|c|c|c|}
\hline \multirow{2}{*}{ Characteristics } & & \multicolumn{2}{|c|}{ PROM } & \multicolumn{2}{|c|}{ Normal } & \multirow{2}{*}{ p value } \\
\hline & & $\mathbf{N}$ & $\%$ & $\mathbf{N}$ & $\%$ & \\
\hline \multirow{4}{*}{ Age (Year) } & $20-25$ & 5 & $21,7 \%$ & 6 & $26,1 \%$ & \multirow{4}{*}{$1,00^{*}$} \\
\hline & $26-30$ & 7 & $30,4 \%$ & 7 & $30,4 \%$ & \\
\hline & $31-35$ & 9 & $39,1 \%$ & 8 & $34,8 \%$ & \\
\hline & $36-40$ & 2 & $8,7 \%$ & 2 & $8,7 \%$ & \\
\hline \multirow{3}{*}{ Parity } & 0 & 11 & $47,8 \%$ & 11 & $47,8 \%$ & \multirow{3}{*}{$1,00^{*}$} \\
\hline & 1 & 7 & $30,4 \%$ & 8 & $34,8 \%$ & \\
\hline & $2-3$ & 5 & $21,7 \%$ & 4 & $17,4 \%$ & \\
\hline \multirow{2}{*}{ Delivery type } & PSP & 6 & $26,1 \%$ & 6 & $26,1 \%$ & \multirow{2}{*}{$1,00 * *$} \\
\hline & $\mathrm{SC}$ & 17 & $73,9 \%$ & 17 & $73,9 \%$ & \\
\hline Total & & 23 & $100 \%$ & 23 & $100 \%$ & \\
\hline
\end{tabular}

*Fisher exact test $\quad * *$ Chi-square test

Table 2: Differences in average thickness and thickness amnion collagen KPD mothers with normal pregnant women.

\begin{tabular}{|c|c|c|c|c|c|}
\hline & Groups & $\mathbf{N}$ & Mean & Std. Deviation & p value ${ }^{* * *}$ \\
\hline \multirow{2}{*}{ Colagen thickness } & PROM & 23 & 108,11 & 14,06 & \multirow{2}{*}{0,001} \\
\hline & Normal & 23 & 172,06 & 38,40 & \\
\hline \multirow{2}{*}{ Amnion thickness } & PROM & 23 & 522,7211 & 85,62632 & \multirow{2}{*}{0,001} \\
\hline & Normal & 23 & 702,7215 & 180,06735 & \\
\hline
\end{tabular}


Based on the type of delivery of the results of the statistical test Chi - square test $\mathrm{p}$ value $>0.05$ showed no significant difference between the type of delivery from mother group with PROM and mother group with normal pregnancy.

In this study also showed that the average thickness of the collagen PROM mother was $108.11 \pm 14.06 \mathrm{~mm}$ thinner than the average thickness of the collagen normal pregnant women is $172.06 \pm 38.40 \mathrm{~mm}$ (Table 2). Statistical test result with t-test $\mathrm{p}$ value $<0.05$, which indicates there is a significant difference of collagen thickness PROM group with normal pregnant women. This suggests that there is relationship between PROM and its collagen thickness.

\section{DISCUSSION}

The characteristic features of collagen is the existence of at least one triple-helical domain comprising a polypeptide chain with a repeating sequence Gly - XY and the ability to form supramolecular aggregates with a structural function in the extracellular matrix (ECM). Collagen is synthesized as procollagen formed in fibroblasts (produce about 5-10\% of total protein), osteoblasts and chondroblasts then be secreted into the extracellular matrix. Collagen contains hydroxyproline and hydroxylysine not found in most other proteins. Hydroxiproline plays an important role in stabilizing the collagen triple helix structure for maximizing the formation of hydrogen bonds between chains. Collagen found in amniotic consists of interstitial collagen types I, III, V, and VI, which are crosslinked and is a major determinant of tensile membrane. ${ }^{6}$

Mediated collagen degradated by matrix metalloproteinase activity which is normally inhibited by specific tissue inhibitors and protease inhibitors. Matrix metalloproteinase, enzymes hydrolyze at least one of the components of the extracellular matrix. metalopreoteinase matrix-1 (MMP-1) and MMP-8, splitting the triple helical structure of collagen type I and type II, which will then be degraded again by gelatinase, MMP-2 and MMP-9. gelatinase also cleave the triple helix collagen type IV, fibronectin, and proteoglycans. In the fetal membranes, MMP-1 and MMP-9 was produced in the epithelial amnion and chorion. ${ }^{7}$

Some experts examined the collagen content of the fetal membranes to show the differences in the architecture of the membrane which is associated with structural abnormality causes, resulting in the occurring of PROM. They saw ratio decreased significantly from type III collagen in patients PROM compared with non - PROM labor and a decrease in total collagen thickness (PROM $350 \pm 70 \mathrm{~g} / \mathrm{mg}$ vs. $587 \pm 84 \mathrm{~g} / \mathrm{mg}, \mathrm{p}<0.01)$. They concluded that the reduction in particular of collagen type III (which serves as a support in the extracellular matrix membrane) would reduce the tensile strength properties of the chorioamniotic membrane. There was a decrease in total collagen content amnion also noted in patients with PROM at different gestational age in the study. ${ }^{2}$

The findings on the increase in MMP-9 instead of MMP1 in the amniotic fluid of women with PROM further confirmed by research by Athayde et al. In this study also found that the average thickness of amniotic mother with PROM was $522.72 \pm 85.63 \mathrm{~mm}$ thinner than the thickness of normal pregnant women amnion is $702.72 \pm 180.07$ $\mathrm{mm}$. Statistical test result with $\mathrm{t}$-test $\mathrm{p}$ value $<0.05$ which showed no significant difference amnion thickness PROM group with normal pregnancy group. This suggests that there is relationship between PROM with its amnion thickness.

Severi et al (2008) conducted research on chorioamniotic membrane thickness measurement with high resolution ultrasound for prediction of preterm labor. Total of 158 women with singleton pregnancy at 18-35 weeks included in the study. The results showed women with preterm labor have chrioamniotic thicker membrane than giving birth at term (1.67 vs. 1.14; $\mathrm{p}<0.001)$. Cut off point assessed by the ROC curve is $1.2 \mathrm{~mm}$ with sensitivity and specificity of $100 \% .^{12}$

The results of the same study reported that the studies showing chorioamniotic thinning in the case of the PROM. Research by Hasaneroglu et al. (2014) in 20 women with PROM and control of 20 women at term pregnancy showed that the cases showed the quantity unit chorioamniotic membrane area lower than in controls $(69.55 \pm 26.3 \%$ vs $49.6 \% \pm 23.44 \% ; p=0.017){ }^{2,5}$ Canzoneri et al (2013) conducted a study to measure the thickness of the membrane and apoptosis choriodesidua in 86 patients chorioamniotic membrane. Immunohistochemistry performed with cytokeratin antibody and thickness of cellular chorionic compared between each group. The results showed chorioamniotic layer is significantly thinner in patients with PROM than patients without PROM preterm labor and delivery patients with sufficient time $(62,140,169$ micrometer $\mathrm{p}$ $<0.001)^{2,6}$

\section{CONCLUSIONS}

From these results it can be concluded that the average thickness of the collagen and thickness of amniotic mother with PROM thinner than the average thickness of the collagen and thickness amniotic normal pregnant women and showed a statistically significant difference in the thickness of the collagen and thickness amnion on PROM group with normal pregnant women. Expected to do further research on the factors that can increase the thickness of the collagen and amniotic to prevent premature labor and PROM.

Funding: No funding sources

Conflict of interest: None declared

Ethical approval: The study was approved by the Institutional Ethics Committee 


\section{REFERENCES}

1. Entin, Suardi A, Haryani L. Gambaran Hasil Luaran Janin pada Persalianan dengan Ketuban Pecah Dini di RSUP Dr. Hasan Sadikin Bandung Tahun 2009. J Pendid Bidan. 2013. ISSN:2089-2225.

2. Rangaswamy N, Kumar D, Moore RM, Mercer BM, Mansour JM, Redline R. Weakening and Rupture of Human Fetal Membranes-Biochemistry and Biomechanics. Pre term birth- mother and child. Intech publishers; 2012. DOI: 10.5772/1284, ISBN 978-953-307-828-1.

3. The American College of Obstetricians and Gynecologists. Premature rupture of membranes. 2013;122(4):918-30.

4. Intitute of obstetricians and gynaecologists. Preterm prelabour rupture of membranes (PPROM); 2015.

5. Cut M. Gambaran Histopatologi dan Tampilan Imunohistokimia Fibronektin Selaput Ketuban pada Perempuan Hamil yang Mendapat Acetylsalicylic Acid (ASA). Dosis Rendah, 2014. Available at: http:/repository.usu.ac.id/handle/123456789/41519. Accessed on 25 September 2015.

6. Putri RE. Perbandingan Ketebalan Selaput Ketuban Pada Ketuban Pecah Dini dan Hamil Normal. Departemen Obstetri dan Ginekologi Fakultas Kedokteran Universitas Sumatera Utara; 2014.
7. Wilfried B. Mechanical characterization and modeling of human fetal membranes tissue; 2014. DOI:10.3929/ethz-a-010147119.

8. Ansari H, Singh A, Zaidi MT, Chandra N. Vasculosyncytial membrane in placental villi of normotensive and hypertensive pregnancies. J Anat Soc India. 2011;60(2):168-170.

9. Chakraborty B, Mandal T, Chakraborty S. Outcome of prelabor rupture of membranes in a tertiary care center in West Bengal. Indian $\mathbf{J}$ Clin Pract. 2013;24(7):657-62.

10. Amstrong-Wells J, Post MD, Donnelly M, MancoJohnson MJ, Fisher BM, Winn VD. Patterns of placental pathology in preterm premature of membranes. J Dev Orig Helath Dis. 2013;4(3):24955 .

11. Hasaneroglu, Bakacak M, Suhhabostanci M, Attar R\& Han A. Relationship between premature rupture of membranes and collagen amount in amniotic membranes in term pregnancy. Global J Med Res. 2014:2(1):23-5.

12. Canzoneri BJ, Feng L, Grotegut CA, Bentley RX, Heine RP, Murtha AP. The chorion layer of fetal membranes is prematurely destroyed in women with preterm premature rupture of the membranes. Rep Sci. 2013:20(10):1246-54.

Cite this article as: Marpaung J. Association between the thickness of the collagen in the amniotic membrane with the incidence of premature rupture of membranes. Int J Reprod Contracept Obstet Gynecol 2016;5:296-9. 